\title{
Pasado y presente de un duelo: Estado-Iglesia
}

El duelo Estado-Iglesia constituyó uno de los clivajes centrales en la formación y consolidación de los Estados nacionales. El conflicto de soberanías entre ambas instituciones se tradujo en una lucha política que tuvo diversas fórmulas de resolución en América Latina, más favorables al clericalismo en algunos casos, al laicismo estatal en otros, o bien -y casi siempre- en la gestación de soluciones de compromiso.Esas tensiones supusieron una suerte de combate en un triple terreno: el económico, vinculado al mantenimiento de la Iglesia a través del presupuesto nacional, exenciones impositivas y subsidios; el político referido a la autonomía de la dirigencia política y las instituciones estatales en los procesos de toma de decisiones; y el cultural, traducido en la lucha en torno a los valores, ideas, códigos y representaciones que debían prevalecer en la sociedad. En un sentido amplio: desde el modelo de mujer hasta la explicación del origen de las estrellas.

En cualquier caso, el hilo conductor que subyace a los distintos tipos de tensiones remite a desafíos del Estado, tanto frente al pensamiento dogmático como a la lógica corporativa de la institución eclesiástica. La edición de este número desde Córdoba, un lugar marcado por la cita entre tendencias tan contrapuestas como las que vieron en ella una ciudad monástica, la «Roma de América del Sur», o bien el meridiano de la Reforma Universitaria argentina y latinoamericana en 1918 o la capital de la patria socialista en los años 70, pone de relieve la necesidad de examinar la pervivencia de estos clivajes en una perspectiva de larga duración, al son de sus nuevos formatos y re-significaciones. De esta manera, se abren las puertas para pensar las relaciones de continuidad y cambio, entre pasado y presente, en los actuales debates que remiten a tradición y modernidad, a laicismo y clericalismo, a dogmatismo y pensamiento crítico.

El contenido de este número tiene una dimensión latinoamericana. Coadyuvaron a su génesis, artículos sobre la problemática de la secularización educativa en Uruguay, Brasil, México y Argentina, uno específico sobre la participación de Iglesia católica en el proceso político brasi- 
leño que condujo al golpe militar de 1964, otro centrado en el debate parlamentario argentino -durante la presidencia de Raúl Alfonsín- sobre el derecho al divorcio vincular y la patria potestad compartida de los padres sobre sus hijos, así como otros referidos al conflicto educativo y la lucha por la hegemonía cultural en la provincia de Córdoba. Sus autores son docentes de las universidades Autónoma de la Ciudad de México (México), de La República (Uruguay), Vale do Rio dos Sinos (Brasil) y de las universidades argentinas: Nacional de Mar del Plata, Nacional de Córdoba y Torcuato Di Tella. Como es de rigor, dos comentarios bibliográficos elaborados por investigadoras del CONICET, coronan la edición de este número.

César Tcach

Director de Estudios 